\title{
Progress in clinical genetics of prostate cancer
}

\author{
C Cybulski*, D Wokołorczyk \\ From Annual Conference on Hereditary Cancers 2009 \\ Szczecin, Poland. 10-11 December 2009
}

Prostate cancer is among the leading causes of morbidity and mortality from cancer in men. Epidemiologic data suggest that dominant susceptibility genes may be responsible for $5 \%-10 \%$ of all of the cases and $30-40 \%$ of early onset cases. Familial clustering of prostate cancer is observed in $10-20 \%$ of men with prostate cancer. Scandinavian study of twins suggests that the heritability of prostate cancer may be as high as $42 \%$. The genetic basis of prostate cancer is complex and appears to involve multiple susceptibility genes. Three candidate susceptibility genes have been positionally cloned - HPC1, HPC2/ELAC2, and MSR1-but a clear role for any of these genes in hereditary prostate cancer has not been established. There is evidence that mutations in BRCA1 or BRCA2 predispose to prostate cancer, but the contribution of these two genes to prostate cancer etiology is relatively small. It has been reported that mutations in NBS1 and CHEK2 may confer moderate increase in the risk of prostate cancer. We found that germline mutations in BRCA1, CHEK2, NBS1 confer increased prostate cancer risk in Polish men. Numerous common low-risk polymorphisms associated with prostate cancer have been reported, many located in genes involved in the DNA damage repair and cell cycle control pathways (i.e. CDKN1B, BRCA2, ATM, XRCC1, XRCC2, ERCC2), however most of these associations have not been replicated. In the past two years, the results of several genome-wide searches for prostate cancer susceptibility loci have been reported. Several chromosomal regions of interest have been identified, including loci on chromosomes 2 , $3,6,7,8,10,11,17,19$ and X. It is believed that identification of genetic markers for prostate cancer will improve prevention, diagnosis and management with prostate cancer.

Published: 1 June 2011

doi:10.1186/1897-4287-9-S2-A6

Cite this article as: Cybulski and Wokołorczyk: Progress in clinical genetics of prostate cancer. Hereditary Cancer in Clinical Practice 20119 (Suppl 2):A6.
Submit your next manuscript to BioMed Central and take full advantage of:

- Convenient online submission

- Thorough peer review

- No space constraints or color figure charges

- Immediate publication on acceptance

- Inclusion in PubMed, CAS, Scopus and Google Scholar

- Research which is freely available for redistribution
() Biomed Central

\section{Biomed Central}

